\title{
Penyuluhan Penggunaan Obat yang Baik Sejak Dini Kepada Siswa Sekolah Menengah Pertama 2 (SMP) Kumai

\author{
Agustoni Pujianto', Mar'atus Shalikah ${ }^{2}$, Siti Aqubah ${ }^{3}$ \\ ${ }^{123}$ STIKes Borneo Cendekia Medika Pangkalan Bun \\ ${ }^{1}$ Email : agustonipujianto32@gmail.com
}

\begin{abstract}
ABSTRAK
Masyarakat Indonesia saat ini sudah mulai terbiasa dengan penggunaan berbagai jenis obat- obatan dengan tujuan menyembuhkan penyakit, mengontrol, ataupun sebagai suplemen untuk menunjang aktifitas sehari-hari. Hal ini dapat disebabkan oleh berbagai faktor seperti perkembangan penyakit, produksi berbagai jenis obatobatan dan suplemen serta mulai diberlakukannya jaminan kesehatan nasional yang memungkinkan masyarakat mendapatkan akses yang lebih mudah untuk mendapatkan pengobatan. Perkembangan tersebut menimbulkan berbagai dampak positif maupun negatif. Dampak positif yang dapat terlihat adalah semakin banyaknya masyarakat yang mulai peduli terhadap kesehatan dengan memeriksakan diri ke tempat-tempat pelayanan kesehatan. Sedangkan dampak negatif yang mungkin timbul dengan meningkatnya penggunaan obat di masyarakat adalah kesalahan dalam menggunakan hingga membuang limbah obat. Hal ini dapat terjadi karena kurangnya pengetahuan dan informasi yang disampaikan kepada masyarakat terkait penggunaan obat yang baik dan benar. Metode yang digunakan dalam pengabdian masyarakat ini diawali dengan adanya pretest, kemudian dilanjutkan dengan pemaparan materi dan ditutup dengan posttest. Setelah pelatihan berakhir diharapkan peserta yang telah memperoleh pengetahuan tentang obat dapat berkelanjutan dan bermanfaat bagi pribadi maupun keluarga.
\end{abstract}

Kata kunci : penggunaan obat, siswa

\section{Extension of good drug use early to junior high school students 2 (SMP) Kumai}

\begin{abstract}
Indonesian society is now getting used to the use of various types of drugs with the aim of curing diseases, controlling, or as a supplement to support daily activities. This can be caused by various factors such as disease progression, production of various types of drugs and supplements as well as the start of a national health insurance guarantee that allows the public to gain easier access to Get treatment. These developments lead to a variety of positive and negative impacts. The positive impact that can be seen is the increasing number of people who begin to care about health by checking into health care places. While the negative impact that may arise with increasing use of the drug in the community is an error in using up to dispose of
\end{abstract}


the drug waste. This can occur due to lack of knowledge and information conveyed to the public regarding the use of good and correct drugs. This method used in community devotion begins with pretest, then proceed with material exposure and closed with posttest. After the training is expected, participants who have gained knowledge about the drug can be sustainable and beneficial for both private and family.

Keywords: drug use, students

\section{PENDAHULUAN}

Masyarakat Indonesia saat ini sudah mulai terbiasa dengan penggunaan berbagai jenis obat- obatan dengan tujuan menyembuhkan penyakit, mengontrol, ataupun sebagai suplemen untuk menunjang aktifitas sehari-hari. Hal ini dapat disebabkan oleh berbagai faktor seperti perkembangan penyakit, produksi berbagai jenis obat-obatan dan suplemen serta mulai diberlakukannya jaminan kesehatan nasional yang memungkinkan masyarakat mendapatkan akses yang lebih mudah untuk mendapatkan pengobatan. Perkembangan tersebut menimbulkan berbagai dampak positif maupun negatif. Dampak positif yang dapat terlihat adalah semakin banyaknya masyarakat yang mulai peduli terhadap kesehatan dengan memeriksakan diri ke tempat-tempat pelayanan kesehatan. Sedangkan dampak negatif yang mungkin timbul dengan meningkatnya penggunaan obat di masyarakat adalah kesalahan dalam menggunakan hingga membuang limbah obat. Hal ini dapat terjadi karena kurangnya pengetahuan dan informasi yang disampaikan kepada masyarakat terkait penggunaan obat yang baik dan benar.
Pengetahuan masyarakat mengenai dunia kesehatan, terutama obat masih sangat terbatas, padahal obat merupakan bahan yang mudah kita temukan di sekitar kita. Obat berperan sangat penting dalam pelayanan kesehatan. Penanganan dan pencegahan berbagai penyakit tidak dapat dijelaskan dari tindakan terapi dengan obat atau farmakoterapi. Berbagai pilihan obat saat ini tersedia, sehingga diperlukan pertimbanganpertimbangan yang cermat dalam memilih obat untuk suatu penyakit. Obat harus selalu digunakan secara benar agar memberikan manfaat klinik yang optimal. (Anidya et al., 2005)

Dalam Undang-Undang Kesehatan No.36 tahun 2009 disebutkan bahwa obat adalah bahan atau paduan bahan, termasuk produk biologi yang digunakan untuk memengaruhi atau menyelidiki sistem fisiologi atau keadaan patologi dalam rangka penetapan diagnosis, pencegahan, penyembuhan, pemulihan, peningkatan kesehatan dan kontrasepsi manusia. Untuk memberikan fungsinya, obat dibuat menjadi bentuk sediaan tertentu yang kemudian dikenal dengan istilah obat jadi, dan obat tersebut mengandung komposisi sesuai denganstandar (Zaman-Joenoes, 2001). Obat paten merupakan obat jadi 
yang dikuasakan untuk diedarkan dengan bungkus asli dari produsen dan masih memiliki hak paten. Obat patensering disebut dengan obat dagang dimana perbedaan obat dagang yang beredar terletak padakecepatan absorpsi obat, kenyamanan penggunaan obat dalam hal rasa dan bau, sertakemudahan obat dicerna (Henry, 2004).

Salah satu elemen yang memiliki keahlian dan dapat menjadi sumber informasimengenai obat adalah apoteker atau farmasis. Peran Apoteker dalam bidang kesehatan yaitu memberikan Konsultasi, Informasi dan Edukasi (KIE), mengarahkan pasien untuk melakukan pola hidup sehat, dan melakukan monitoring. Hasil terapi pengobatan yang telah dijalankan oleh pasien merupakan kerja sama dengan profesi kesehatan lain yang tentunya bertujuan untuk meningkatkan kualitas hidup pasien (Astika, 2003). Tetapi, dari hasil surveyternyata masyarakat masih kurang mengenal siapa apoteker dan bagaimana dunianya sehingga akses masyarakat untuk mendapatkan informasi obat juga terbatas. Karena pengetahuan mengenai obat yang terbatas tersebut maka banyak timbul permasalahan dalam penggunaan obat.

\section{METODE PENELITIAN}

Materi sosialisasi tentang penggolongan obat, jenis obat, informasi pada kemasan dan brosur obat, cara penggunaan obat, efek samping obat, cara penyimpanan obat, obat rusak dan kadaluwarsa. Sebelum penyampaian materi, dilaksanakan pre test terlebih dahulu untuk mengetahui tingkat pemahaman dan pengetahuan siswa. Setelah dilakukan pre test, Peserta juga diberikan simulasi atau praktek langsung berdasarkan teori atau materi yang telah diberikan sebelumnya meliputi praktek mengenal golongan obat, membaca informasi pada kemasan dan brosur obat, menganalisis efek samping obat seperti yang tercantum dalam kemasan. Masing-masing siswa mendapatkan satu botol multivitamin sehingga dapat digunakan untuk mempraktekkan bagaimana cara minum obat sesuai dengan dosis yang tercantum dalam kemasan, menentukan berapa frekuensi penggunaan dalam sehari sesuai dengan aturan penggunaan yang tercantum dalam kemasan, serta bagaimana cara menyimpan obat dengan benar setelah kemasan dibuka. Evaluasi keberhasilan pemberian penyuluhan tahap pertama dilakukan dengan cara memberikan pertanyaan mengenai materi yang sudah diberikan. Siswa yang menjawab pertanyaan dengan tepat mendapatkan hadiah yang sudah disiapkan oleh tim.

\section{HASIL DAN PEMBAHASAN}

Kegiatan ini berupa penyuluhan mengenai pengenalan obat.Penyuluhan dilaksanakan di SMP 2 Kumai. Tujuan kegiatan ini adalah meningkatkan pengetahuan siswa mengenai obat 
sehingga akan meningkatkan kepatuhan siswa untuk minum. Sebelum penyampaian materi, dilaksanakan pre test terlebih dahulu untukmengetahui tingkat pemahaman dan pengetahuan siswa. Hasil pre-test ini akan dibandingkan dengan hasil post-test yang akan dikerjakan setelah siswa mendapatkan penyuluhan. Setelah pre-test siswa diajak berkenalan terlebih dahulu dengan para pemateri, tujuannya agar siswa dapat lebih mudah berinteraksi sehingga materi yang diberikan dapat diterima dengan baik. Dosen sebagai pemateri menyampaikan materi selama 1 jam yang diselingi dengan Tanya jawab dan permainan. Peserta juga diberikan simulasi atau praktek langsung berdasarkan teori atau materiyang telah diberikan sebelumnya meliputi praktek mengenal golongan obat, membaca informasi pada kemasan dan brosur obat, menganalisis efek samping obat seperti yangtercantum dalam kemasan. Masing-masing siswa mendapatkan satu botol multivitamin sehingga dapat digunakan untuk mempraktekkan bagaimana cara minum obat sesuai dengan dosis yang tercantum dalam kemasan, menentukan berapa frekuensi penggunaan dalam sehari sesuai dengan aturan penggunaan yang tercantum dalam kemasan, serta bagaimana cara menyimpan obat dengan benar setelah kemasan dibuka. Evaluasi keberhasilan pemberian penyuluhan tahap pertama dilakukan dengan cara memberikan pertanyaan mengenai materi yang sudah diberikan. Siswa yang menjawab pertanyaan dengan tepat mendapatkan hadiah yang sudah disiapkan oleh tim. Kegiatan terakhir adalah evaluasi yaitu siswa dibagikan lembar post test dan kemudian dikumpulkan untuk dinilai. Siswa kelas 10 A yang mengikuti kegiatan sejumlah 24 siswa, dimana nilai rata-rata pre test adalah 57,08 sedangkan nilai rata-rata post test adalah 72,17. Jumlah siswa kelas 10 B yang mengikuti sebanyak 26 siswa, dimana nilai rata-rata pre test sebesar 70,00 sedangkan nilai post test sebesar 83,46 . Pada tabel 1 menunjukkan bahwa adanya perbedaan nilai antara pre test dan post test, dimana hasil nilai rata-rata post test lebih tinggi daripada pre test. Hasil ini menunjukkan bahwa pemberian penyuluhan mengenai obat dan dapat diterima dengan baik oleh siswa. Materi penyuluhan yang diberikan dapat meningkatkan pengetahuan siswa mengenai informasi terkait obat terbukti dengan peningkatan nilai post test yang diperoleh siswa. Hal ini menunjukkan bahwa adanya pengaruh hasil penyampaian materi terhadap tingkat pemahaman dan pengetahuan tentang dan obat sebelum dan sesudah materi dilaksanakan dalam kegiatan ini. Kegiatan ini mendapatkan tanggapan yang positif dari semua pihak, baik pihak sekolah yang diwakili para guru dan kepala sekolah maupun dari pihak siswa. Siswa sangat bersemangat ketika mengikuti materi, mereka juga saling berebutan untuk menjawab pertanyaan yang diberikan. Hal tersebut menunjukkan antusiasme siswa yang sangat besar. Siswa juga sangat tertarik ketika 
mereka dapat praktek membaca leaflet/brosur obat maupun cara minum obat. Diharapkan kegiatan ini dapat memberikan manfaat yang besar, baik untuk siswa sendiri maupun pihak sekolah.

\section{KESIMPULAN DAN SARAN}

\section{Kesimpulan}

Kesimpulan yang dapat diambil dari kegiatan pengabdian ini adalah masih rendahnya pengetahuan siswa sekolah menengah pertama tentang jenis dan golongan obat beserta cara penggunaan dan penyimpanannya, serta jenis obat. Pemberian penyuluhan terbukti dapat meningkatkan pengetahuan siswa. Kegiatan ini mendapatkan sambutan yang positifdari pihak guru dan kepala sekolah serta diikuti dengan sangat antusias oleh seluruh siswa.

\section{Saran}

Setelah pelatihan berakhir diharapkan peserta yang telah memperoleh pengetahuan tentang obat dapat berkelanjutan dan bermanfaat bagi pribadi maupun keluarga.

\section{DAFTAR PUSTAKA}

Anief M., 2007, Ilmu Meracik Obat, Gadjah Mada University Press, Yogyakarta

Anidya, C. M., Taufikurrakhman, A., Akbar, Z., Ningsih, S., Farmasi, P. S., \& Indonesia, U. I. (2005). Upaya
Membangkitkan Eksistensi Profesi Apoteker Dan Sistem Interpersonal Education, 3540.

Astika, S.L., dalam Charles, S., dan Lia, A., 2003, Farmasi Rumah Sakit : Teori Dan Terapan, EGC, Jakarta, 177178.

Barnes, J., Anderson, L.A., Phillipson, J.D. (2005). Herbal medicines.

London:Pharmaceutical Press.

BPOM. (2008). Pengetahuan Tentang Obat: Perlunya Pendekatan dari Perspektif Masyarakat. Majalah Info POM Vol. 9 No. 4

Depkes RI. (2008). Pedoman Pelatihan Dokter Kecil. Direktorat Bina Kesehatan Anak. Depkes RI

Kurnia, N., Suswandari, M., Sari, N. K., \& Suswandari, M. (2016). Effektivitas Program Apoteker Kecil ( Apcil ) Terhadap Pengetahuan Tanaman Obat Tradisional Keluarga Di Sekolah Dasar Negeri 2 Sukoharjo Tahun Ajaran 2015 / 2016. (Kurnia, Suswandari, Sari, \& Suswandari, 2016) 